\title{
Biological activity of benzoxazolinone and benzoxazolinthione derivatives
}

\author{
$K$ Giyasov$^{1}, G$. S. Turaeva ${ }^{1, *}$, and $H T$ Turaeva $^{1}$ \\ ${ }^{1}$ Tashkent State Agrarian University, University str., 2, Tashkent province, 100140, Uzbekistan
}

\begin{abstract}
The article presents the herbicidal, defoliating, fungicidal properties of the synthesized derivatives of benzoxazolinones and benzoxazolinethions. It was shown that 3-alkylbenzoxazolinones, 3-alkyl6-halobenzoxazolinones and 2-alkylthiobenzoxazoles exhibit herbicidal action during the growing season of plants, and they also cause cotton leaves to drop up to $70 \%$. It was found that 3 -alkylbenzoxazolinones and 2-alkylthiobenzoxazoles exhibited fungicidal activity against the pathogen, Fugarium oxyporum and Verticillum dahlia. Among them, 2methylthiobenzoxazole inhibited spores of the fungi Verticillum dahlia by $96.4 \%$ and benzoxazolyl-2-carbamic acid butyl ester by $65 \%$. These compounds exhibit fungicidal action against the pathogens of powdery mildew on cucumbers - Erysiphe cichoraceorum and powdery mildew on wheat - Erysiphe graminis, approaching the control Karatan. Apparently, these compounds are chemicals of contact action.
\end{abstract}

\section{Introduction}

The government attaches great importance to the further development of agriculture. An essential place in these measures is given to the chemicalization of agriculture and animal husbandry. In recent years, a number of important decrees have been adopted that have determined the main directions for the development of the chemical industry [1, 10-18]. The government drew attention to the need for a broad development of scientific research on the creation of herbicides, fungicides and preparations for the control of pests of agricultural crops, the organization of the search and industrial production of new pesticides $[2,19-21]$

The improvement of chemical compounds for plant protection hearts is an urgent task. Pathogenic organisms develop resistance to active substances with their regular use $[4,6$, 7]. In this regard, the search for new compounds with high biological effectiveness in suppressing the development and spread of infection is of both theoretical and practical interest $[3,5]$. At the same time, systemic chemicals possessing both protective and healing properties are of particular value $[8,9]$.

Among the derivatives of benzoxazolinone and its sulfur analogue-benzoxazolinethione, a number of biologically active substances are known. Benzoxazolinone in small doses stimulates and in significant doses inhibits seed growth, i.e. manifests itself as a natural

\footnotetext{
*Corresponding author: gulzoda2002@gmail.com
} 
plant growth regulator. Benzoxazolinone and its 6-methoxy-substituted one have a systemic fungicidal effect [4]. Even more powerful fungicides are 6-halogen-substituted benzoxazolinones, which have been proposed as means of protection against the destruction of textiles, paper, wool, and other materials by microorganisms. In this series of compounds, herbicides are also known [7]. A patented method of weed control using 2benzylthiobenzoxazoles [10]. There is information on the selectivity in the fight against broad-leaved weeds substituted in the core of benzoxazolinethions [11]. Esters of $(\beta-$ (benzoxazolylthio) -acrylic acids exhibit inverse selectivity, acting only against narrowleaved weeds [12]. A number of benzoxazolinone and benzoxazolinethione derivatives have been proposed as insecticides. Among them O, O-diethylthiophosphorylmethyl-6chlorobenzoxazolinone which is widely used in agriculture as a substitute for DDT [13] some derivatives of 10-benzazolylthiophenoxarsine [14] have insecticidal, fungicidal, and herbicidal activity.

\section{Materials and methods}

Analysis of literature data on the biological activity of benzoxazolinone (BN) and benzoxazolinethione (BT) derivatives allows us to conclude that their alkyl derivatives have pesticidal activity.

The 3-alkylbenzoxazolinones (1 a - c), 2-alkylthiobenzoxazoles ( $2 \mathrm{a}-\mathrm{h})$ and alkyl esters of benzoxazolyl-2-carbamic acid (3 a - d) synthesized in this work were tested as pesticides in the corresponding laboratories of the Institute of Plant Chemistry AS RUz and Uzbek Research Institute of Plant Protection AS RUz.

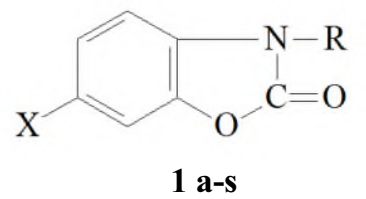

\section{3-alkylbenzoxazolinones (1a-c)}

Where 1a $\mathbf{R}=\mathbf{H}, \mathbf{X}=\mathbf{H}$;

b. $\mathrm{R}=\mathrm{CH}_{3}, \mathrm{X}=\mathbf{H}$;

v. $\mathrm{R}=\mathrm{C}_{2} \mathrm{H}_{5}, \mathrm{X}=\mathrm{H}$;

g. $\mathrm{R}=\mathrm{C}_{3} \mathrm{H}_{7}, \mathrm{X}=\mathrm{H}$;

d. $\mathrm{R}=\mathrm{C}_{4} \mathrm{H}_{9}, \mathrm{X}=\mathrm{H}$;

e. $\mathrm{R}=-\mathrm{C} 5 \mathrm{H}_{11}, \mathrm{X}=\mathrm{H}$;

j. $\mathrm{R}=-\mathrm{C}\left(\mathrm{C}_{6} \mathrm{H}_{5}\right)_{3}, \mathrm{X}=\mathrm{H}$;

z. $\mathrm{R}=-\mathrm{CH}=\mathrm{CH}_{2}, \mathrm{X}=\mathrm{H}$;

i. $\mathrm{R}=-\mathrm{CH}_{2}-\mathrm{CH}=\mathrm{CH}_{2}, \mathrm{X}=\mathrm{H}$;

k. $\mathrm{R}=\mathrm{CH}_{3}, \mathrm{X}=\mathrm{Cl}$;

l. $\mathrm{R}=\mathrm{C}_{2} \mathrm{H}_{5}, \mathrm{X}=\mathrm{Cl}$;

m. $\mathrm{R}=\mathrm{C}_{3} \mathrm{H}_{7}, \mathrm{X}=\mathrm{Cl}$;

n. $\mathrm{R}=\mathrm{C}_{4} \mathrm{H}_{9}, \mathrm{X}=\mathrm{Cl}$;

o. $\mathrm{R}=-\mathrm{CH}=\mathrm{CH}_{2}, \mathrm{X}=\mathrm{Cl}$

p. $\mathrm{R}=-\mathrm{CH}_{2}-\mathrm{CH}=\mathrm{CH}_{2}, \mathrm{X}=\mathrm{Cl}$;

q. $\mathrm{R}=-\mathrm{C}\left(\mathrm{C}_{6} \mathrm{H}_{5}\right)_{3}, \mathrm{X}=\mathrm{Cl}$;

s. $\mathrm{R}=\mathrm{CH}_{3}, \mathrm{X}=\mathrm{Br}$;

t. $\mathrm{R}=\mathrm{C}_{2} \mathrm{H}_{5}, \mathrm{X}=\mathrm{Br}$;

u. $\mathbf{R}=\mathrm{C}_{3} \mathrm{H}_{7}, \mathrm{X}=\mathrm{Br}$;

f. $\mathrm{R}=-\mathrm{C}\left(\mathrm{C}_{6} \mathrm{H}_{5}\right)_{3}, \mathrm{X}=\mathrm{Br}$;

kh. $\mathrm{R}=-\mathrm{CH}=\mathrm{CH}, \mathrm{X}=\mathrm{Br}$;

ts. $\mathrm{R}=-\mathrm{CH}_{2}-\mathrm{CH}=\mathrm{CH}_{2}, \mathrm{X}=\mathrm{Br}$; 


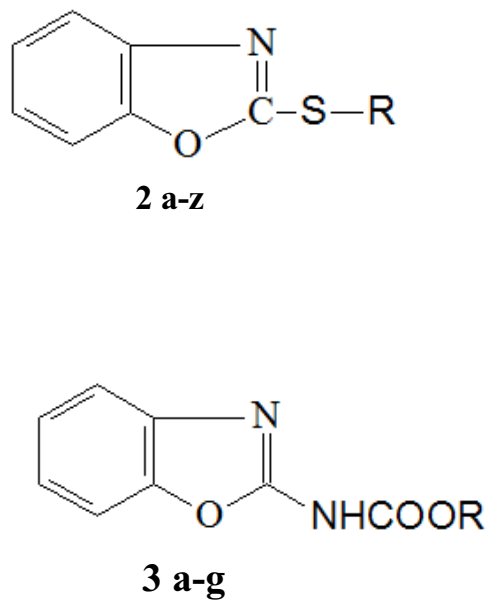

\section{2-alkylthiobenzoxazoles (2a-h)}
Where 2a. $\mathrm{R}=\mathrm{CH}_{3}$, b. $\mathrm{R}=\mathrm{C}_{2} \mathrm{H}_{5}$, в $\mathrm{R}=\mathrm{C}_{3} \mathrm{H}_{7}$, g. $\mathrm{R}=\mathrm{C}_{4} \mathrm{H}_{9}, \mathrm{~d} \mathrm{R}=\mathrm{C}_{5} \mathrm{H}_{11}$, e. $\mathrm{R}=-\mathrm{CH}_{2} \mathrm{C}_{6} \mathrm{H}_{5}$, j. $\mathrm{R}=-\mathrm{CH}=\mathrm{CH}_{2}$, z. $\mathrm{R}=-\mathrm{CH}_{2}-\mathrm{CH}=\mathrm{CH}_{2}$.

\section{Alkyl ethers of benzoxazolyl- 2-carbamic acid (3a-d)}

Where 3a $\mathrm{R}=\mathrm{CH}_{3}$;
b. $\mathbf{R}=\mathbf{C}_{2} \mathrm{H}_{5}$,
v. $\mathbf{R}=\mathrm{C}_{3} \mathrm{H}_{7}$;
g. $\mathrm{R}=\mathrm{C}_{4} \mathrm{H}_{9}$

The herbicidal activity of the compounds was studied in laboratory conditions on the roots and seedlings of cucumbers, radishes, oats, chicken millet, cabbage and cotton. The seeds of the test plants were sown in Petri dishes on an agar medium containing various doses of the herbicide and germinated for 7 days at a temperature of $26{ }^{\circ} \mathrm{C}$. The herbicidal activity was judged by the length of the root in comparison with the control (without herbicide). The preparations were applied in the form of aqueous emulsions at a dose of 5 $10 \mathrm{~kg} / \mathrm{ha}$ (according to the current principle). ED50 was used as an indicator of activity, i.e. dose causing $50 \%$ inhibition of root growth (kg/ha). The test results are shown in Table 1.

The results of the test on roots and seedlings showed that the most sensitive test plants were cucumbers, oats and radishes. In the series of 3-alkylbenzoxazolinones, 3methylbenzoxazolinone was most active (1b, Table 1), where the ED50 for oats and radishes was 1.5-3.4, and for cucumber and cabbage - 4.3.

The introduction of electronegative atoms into the 6-position of benzoxazolinone led to an increase in the herbicidal action (compare $1 \mathrm{~b}$ with $1 \mathrm{c}$ and $1 \mathrm{y}$ of Table 1), where the ED50 of almost all (except cabbage) test plants averaged 1.9. Of the 2alkylthiobenzoxazoles, the most active were 2-methylthiobenzoxazole (2a) and 2ethylthiobenzoxazole (2b) where ED50, for almost all test plants averaged 2.5. From the data in Table 1, it can be seen that with an increase in the length of the alkyl radical in 2alkylthiobenzoxazoles, the herbicidal activity decreases: $\mathrm{CH} 3>\mathrm{C} 2 \mathrm{H} 5>\mathrm{C} 3 \mathrm{H} 7>\mathrm{C} 4 \mathrm{H} 9>$ C5H11

Further, the study of the properties of the synthesized compounds as inhibitors of photosynthesis was carried out. Chlorella is a sensitive test for the detection of herbicides that inhibit photosynthesis and respiration. Chlorella tests were carried out according to the method [20]. The chlorophyll content was determined on a photoelectric colorimeter with a blue light filter. The herbicidal activity was judged by the drop in chlorophyll density. When tested on chloral, 2-alkylthiobenzosazoles exhibited greater activity than 3alkylbenzosazolinones (Table 2). 
Table 1. Herbicidal activity of benzoxazolinone and benzoxazolinethione derivatives.

\begin{tabular}{|c|c|c|c|c|c|c|c|c|c|c|}
\hline \multirow{3}{*}{ \# } & \multirow{3}{*}{ Compound } & \multicolumn{8}{|c|}{ Units $\mathbf{E D}_{50}$} & \multirow{3}{*}{ Chlorella } \\
\hline & & \multicolumn{2}{|c|}{ Cucumbers } & \multicolumn{2}{|c|}{ Oats } & \multicolumn{2}{|c|}{ Radish } & \multicolumn{2}{|c|}{ Cabbage } & \\
\hline & & root & Proros & root & Proros & root & Proros & root & Proros & \\
\hline 1 & Benzoxazolinone (1a) & 8 & 5 & 1.5 & 5 & 5 & 8.4 & 8.2 & 7.5 & $7.2 \cdot 10^{-4}$ \\
\hline 2 & 3-methylbenzoxazolinone (1b) & 4.3 & 6.1 & 1.5 & 1.0 & 3.4 & 3.3 & 3.4 & 4.2 & $6.1 \cdot 10^{-4}$ \\
\hline 3 & 3-ethylbenzoxazolinone (1c) & 9 & 8.7 & 2.7 & 3.3 & 5 & 6.9 & 5 & 10 & $6.1 \cdot 10^{-2}$ \\
\hline 4 & 3-propylbenzoxazolinone (1g) & 5 & 5 & 3.1 & 4.1 & 7.5 & 5 & 3.9 & 7.2 & $5.1 \cdot 10^{-4}$ \\
\hline 5 & 3-butylbenzoxazolinone (1e) & 5 & 5 & 2.5 & 2.5 & 10 & 5 & 5 & 5 & $5.1 \cdot 10^{-2}$ \\
\hline 6 & 3-amylbenzoxazolinone (1e) & 7.2 & 10 & 7.1 & 5.9 & 10 & 10 & 10 & 10 & $8.8 \cdot 10^{-2}$ \\
\hline 7 & $\begin{array}{c}\text { 3-methyl-6- } \\
\text { chlorobenzoxazolinone (1c) }\end{array}$ & 2.1 & 2.9 & 2.7 & 2.5 & 2.9 & 2.3 & 8.5 & 8.7 & $8.2 \cdot 10^{-4}$ \\
\hline 8 & $\begin{array}{c}\text { 3-methyl-6- } \\
\text { bromobenzoxazolinone (1c) }\end{array}$ & 3.7 & 3.6 & 8.6 & 3.2 & 2.3 & 3.8 & 8.9 & 9.1 & $8.2 \cdot 10^{-4}$ \\
\hline 9 & $\begin{array}{c}\text { 3-ethyl-6-chlorobenzoxazolinone } \\
\text { (1L) }\end{array}$ & 2.7 & 1 & 3 & 1.9 & 1 & 1.6 & 9.5 & 8.8 & $6.7 \cdot 10^{-4}$ \\
\hline 10 & $\begin{array}{c}\begin{array}{c}\text { 3-ethyl-6-bromobenzoxazolinone } \\
\text { (s) }\end{array} \\
\end{array}$ & 2.4 & 4 & 2.3 & 1 & 4 & 1.6 & 3 & 2.3 & $6.3 \cdot 10^{-4}$ \\
\hline 11 & $\begin{array}{c}\text { 3-propyl-6-chlorobenzoxazolinone } \\
(\mathrm{m})\end{array}$ & 2.8 & 1 & 7 & 5 & 10 & 10 & 10 & 10 & $6.3 \cdot 10^{-3}$ \\
\hline 12 & $\begin{array}{c}\text { 3-propyl-6-bromobenzoxazolinone } \\
(1 \mathrm{y})\end{array}$ & 1.9 & 1 & 1.2 & 3 & 2 & 2.5 & 9.6 & 8.5 & $6.3 \cdot 10^{-3}$ \\
\hline 13 & $\begin{array}{c}\text { 3-butyl-6-chlorobenzoxazolinone } \\
(1 \mathrm{n})\end{array}$ & 2.1 & 5 & 2.2 & 1.8 & 10 & 10 & 10 & 10 & $6.3 \cdot 10^{-3}$ \\
\hline 14 & 2-methylthiobenzoxazole (2a) & 1.9 & 3.2 & 1 & 3.2 & 3 & - & 2.8 & 2.8 & $6.3 \cdot 10^{-5}$ \\
\hline 15 & 2-ethylthiobenzoxazole (2b) & 1.6 & 3.2 & 1.6 & 1.3 & 3.4 & 2.7 & 3.6 & 3.6 & $7.4 \cdot 10^{-5}$ \\
\hline 16 & 2-propylthiobenzoxazole (2c) & 1.6 & 2.8 & 1.8 & 1.3 & 3.7 & 3.7 & 1.9 & 3 & $7.4 \cdot 10^{-4}$ \\
\hline 17 & 2-butylthiobenzoxazole $(2 \mathrm{~g})$ & 2.1 & 3.5 & 2.1 & 5.8 & 5 & 4.2 & 1.3 & 3 & $7.4 \cdot 10^{-3}$ \\
\hline 18 & 2-amylthiobenzoxazole (2e) & 2 & 7 & 9.1 & 6.2 & 10 & 10 & 10 & 10 & $3.8 \cdot 10^{-4}$ \\
\hline
\end{tabular}

Table 2. Herbicidal activity of compounds when processing vegetative plants.

\begin{tabular}{|c|c|c|c|c|c|c|c|c|c|}
\hline \multirow[b]{2}{*}{$\#$} & \multirow[b]{2}{*}{ Compound } & \multirow[b]{2}{*}{ 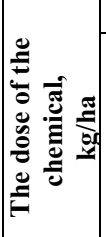 } & \multicolumn{7}{|c|}{ Inhibition of the weight of the raw mass, $\%$ of control } \\
\hline & & & $\stackrel{\Xi}{\stackrel{\Xi}{0}}$ & 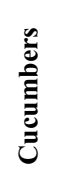 & 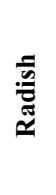 & $\stackrel{\mathscr{E}}{:}$ & 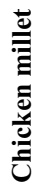 & 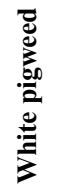 & $\frac{5}{50}$ \\
\hline 1 & $\begin{array}{c}\text { 3-methyl-6-bromobenzoxazolinone } \\
(1 \mathrm{c})\end{array}$ & 10 & - & - & 20 & 30 & - & 40 & 40 \\
\hline 2 & 3-ethylbenzoxazolinone (1c) & 10 & - & 5 & 10 & - & 5 & 10 & 15 \\
\hline 3 & 2-ethylthiobenzoxazole (2b) & 10 & 20 & 20 & - & - & 20 & 80 & 40 \\
\hline 4 & $\begin{array}{c}\begin{array}{c}\text { Z-propyl-6-chlorobenzoxazolinone } \\
(1 \mathrm{~m})\end{array} \\
\end{array}$ & 10 & 10 & 100 & - & 10 & 10 & 10 & - \\
\hline 5 & 3-allylbenzoxazolinone (1i) & 10 & 30 & - & - & 20 & 20 & 20 & 20 \\
\hline 6 & $\begin{array}{l}\text { 3-allyl-6-chlorobenzoxazolinone } \\
(1 \mathrm{p})\end{array}$ & 10 & 40 & - & - & 70 & 20 & 20 & 20 \\
\hline 7 & $\begin{array}{l}\text { 3-allyl-6-bromobenzoxazolinone } \\
\text { (1c) }\end{array}$ & 10 & 30 & 100 & - & 60 & 60 & 80 & 80 \\
\hline 8 & 2-methylthiobenzoxazole (2a) & 10 & 10 & - & 100 & 100 & 10 & 100 & 100 \\
\hline 9 & 2-butylthiobenzoxazole (2g) & 10 & 30 & - & 100 & 70 & 50 & 60 & 40 \\
\hline 10 & 2-allylthiobenzoxazole $(2 \mathrm{~h})$ & 10 & 20 & - & - & - & - & 80 & 60 \\
\hline
\end{tabular}


In addition to a qualitative assessment of herbicidal activity, a quantitative assessment has also been carried out [21]. The obtained qualitative data on activity correlate with the quantitative assessment based on the regression equation. For this purpose, a series of synthesized 3-alkylbenzoxazolinones and 2-alkylthiobenzoxazoles was divided into three groups:<smiles>[X]c1ccc2c(c1)oc(=O)n2[R]</smiles><smiles>[X]c1ccc2c(c1)oc(=O)n2[R]</smiles><smiles>[R]Sc1nc2ccccc2o1</smiles>

2 a-d
3 - alkylbenzoxazolinones (1a-e) where 1a $\mathrm{R}=\mathrm{H}, \mathrm{X}=\mathrm{H}$; $6 \mathrm{R}=\mathrm{CH}_{3}, \mathrm{X}=\mathrm{H}$; $\mathrm{v} \mathbf{R}=\mathrm{C}_{2} \mathrm{H}_{5}, \mathrm{X}=\mathrm{H}$; г $\mathrm{R}=\mathrm{C}_{3} \mathrm{H}_{7}, \mathrm{X}=\mathrm{H}$; r R= $\mathrm{C}_{4} \mathrm{H}_{9}, X=\mathrm{H}$; e $\mathrm{R}=\mathrm{C}_{5} \mathrm{H}_{11}, \mathrm{X}=\mathrm{H}$;.

\section{3 - alkyl-6-halobenzoxazolinones (1k-u)}

Where $1 \mathrm{k} \mathrm{R}=\mathrm{CH}_{3}, \mathrm{X}=\mathrm{Cl}$;

1 I R $=\mathrm{C}_{2} \mathrm{H}_{5}, \mathrm{X}=\mathrm{Cl}$;

$1 \mathrm{~m} \mathrm{R}=\mathrm{C}_{3} \mathrm{H}_{7}, \mathrm{X}=\mathrm{Cl}$;

1n $\mathrm{R}=\mathrm{C}_{4} \mathrm{H}_{9}, \mathrm{X}=\mathrm{Cl}$,

1c $\mathrm{R}=\mathrm{CH}_{3}, \mathrm{X}=\mathrm{Br}$,

1t $\mathrm{R}=\mathrm{C}_{2} \mathrm{H}_{5}, \mathrm{X}=\mathrm{Br}$;

1u $\mathrm{R}=\mathrm{C}_{3} \mathrm{H}_{7}, \mathrm{X}=\mathrm{Br}$.

2 - alkylthiobenzoxazoles (2a-e)

where $2 \mathrm{a} \mathrm{R}=\mathrm{CH}_{3}$,

2b $\mathrm{R}=\mathrm{C}_{2} \mathrm{H}_{5}$,

$2 \mathrm{~V} \mathrm{R}=\mathrm{C}_{3} \mathrm{H}_{7}$,

$2 \mathrm{~g} \mathrm{R}=\mathrm{C}_{4} \mathrm{H}_{9}$,

$2 \mathrm{~d} \mathbf{R}=\mathrm{C}_{5} \mathrm{H}_{11}$.

\section{Results and discussion}

To obtain a more active compound from group 1 a-e on cucumbers and cabbage, it is necessary to introduce electropositive groups and on oats, radishes - electronegative groups. An increase in the herbicidal activity of compounds of the $1 \mathrm{k}-\mathrm{y}$ group on cucumbers and cabbage can also be achieved by the introduction of electropositive groups, and on radish electronegative.

For the 2 a-e group of compounds, a satisfactory correlation is obtained only on oats; here, in order to increase the activity, it is necessary to introduce electronegative groups into the molecule at the sulfur atom. The difficulty of correlation for other plants is possibly related to the chemical properties of the sulfur atom.

Thus, the study of the quantitative relationship between biological activity and chemical structure allows the targeted synthesis of compounds with desired properties. Using the $\mathrm{C}$ Hansch correlation equation, it was established that the manifestation of herbicidal activity is of decisive importance for the electronic characteristics of the substituents.

The compounds synthesized by us were tested as herbicides at a dose of $5-10 \mathrm{~kg} / \mathrm{ha}$ (according to the effective beginning) in the post-emergence period. The objects of study were cotton, radish, wheat, chicken simply, white cheese and shiritsa. The results obtained are presented in Table 3. As can be seen from the data in this table, the introduction of a 
halogen in the 6-position of benzosazolinone enhances the herbicidal activity (1i and $1 \mathrm{n}$ of Table 3). Replacing chlorine with bromine increases the activity (compare 1n and 1c of Table 3).

The highest herbicidal activity was shown by 2-alkylthiobenzoxazoles. Among them, 2methylthiobenzoxazole exhibits a high percentage of weed suppression (Table 3). Extensive field trials in recent years have confirmed the high herbicidal activity of this compound.

Thus, the results obtained allow us to conclude that 3-alkylbenzoxazolinones, 3-alkyl-6galloidbenzoxazolinones and 2-alkylthiobenzoxazoles, like carboxylic acid arylamides, exhibit herbicidal action during the growing season of plants. Apparently, they are chemicals of contact action. On the basis of this conclusion, the synthesized 3alkylbenzoxazolinones and 2-alkylthiobenzoxazoles were transferred for study for defoliating activity. The results given in Table 3 shows that they cause up to $70 \%$ drop in cotton leaves. However, it seems to us that among 3-alkylbenzoxazolinones and 2alkylthiobenzoxazoles, chemicals with high defoliation activity should be expected.

Table 3. Defoliating activity of benzoxazolinone and benzoxazolinethione derivatives.

\begin{tabular}{|c|c|c|c|c|c|}
\hline \multirow[b]{2}{*}{ \# } & \multirow[b]{2}{*}{ Compound } & \multicolumn{2}{|c|}{6 day } & \multicolumn{2}{|c|}{12 day } \\
\hline & & 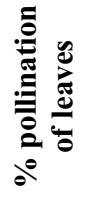 & 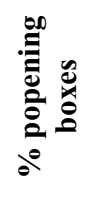 & 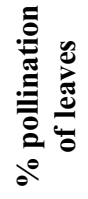 & 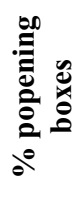 \\
\hline 1 & 3-methylbenzoxazolinone (1b) & 46.3 & 28 & 59 & 62.2 \\
\hline 2 & 2-methylthiobenzoxazole (2a) & 53.3 & 33.0 & 62.8 & 52.9 \\
\hline 3 & 3-butylbenzoxazolinone (1e) & 45.2 & 61.8 & 57.4 & 71.4 \\
\hline 4 & 3-amylbenzoxazolinone (1e) & 23.1 & $56.6 \mathrm{I}$ & 36.5 & 64.2 \\
\hline 5 & $\begin{array}{l}\text { 3-methyl-6-bromobenzoxazolinone } \\
\text { (1c) }\end{array}$ & 41.0 & 54.1 & 54.0 & 70.8 \\
\hline 6 & $\begin{array}{l}\text { 3-methyl-6-chlorobenzoxazolinone } \\
\text { (1c) }\end{array}$ & 48.6 & 45.6 & 66.0 & 65.2 \\
\hline
\end{tabular}

The aim of the work was laboratory testing of new derivatives of benzoxazolinone and benzoxazolitinone to reveal their fungicidal activity. The tests involved 19 new compounds.

The studies of new compounds were carried out in a vegetation experiment performed according to the generally accepted method on cucumber and wheat crops. Used genetically unstable to infection varieties of cucumber "Multiple VSHV" and wheat "Krasnozernaya". The pathogenic fungi Fusarium oxysporum and Verticillum dahlia (causative agents of wilt) and Erysiphe cichoracearum and Erysiphe graminis (causative agents of powdery mildew) were used as test organisms. To assess the effect of the compounds, the suppression of the development of pathogenic organzymes on plants was determined.

The fungicidal activity of the synthesized compounds is due to the suppression of metabolic processes in the mycelium of fungi. When searching for new active substances for the creation of plant protection products, compounds are presented that have a point effect only on pathogenic organisms. The 3-alkylbenzoxazolinones (1 a-c) 2alkylthiobenzoxazoles ( 2 a-h) and alkyl esters of benzoxazolyl-2-carbamic acid (3 a-d) [1519] synthesized in this work were tested as fungicides in the phytotaxigology laboratory of the Institute of Plant Chemistry AS RUz.

3-alkylbenzoxazolinones, 3-tritylbenzoxazolinones, 2-alkylthiobenzoxazoles, and alkyl esters of benzoxazolyl-2-carbamic acid showed weak fungicidal activity on the mycelium 
of Fusarium oxyporum and Verticillum dahlia fungi, among them 2-methylthiobenzoxazole suppressants\%. The fungicidal activity of 2-vinylthiobenzoxazole is better than that of 3vinylbenzoxazolinone. 3-tritylbenzoxazolinones showed weak fungicidal activity (Table 4).

Table 4. Antiviltic activity suppression of development, \% of synthesized compounds.

\begin{tabular}{|c|c|c|c|}
\hline$\#$ & Compound & $\begin{array}{c}\text { Fusarium } \\
\text { oxyporum }\end{array}$ & $\begin{array}{c}\text { Verticillum } \\
\text { dahlia }\end{array}$ \\
\hline 1 & $\begin{array}{l}\text { Control-BMK (Benzimidazolyl-2-carbamic } \\
\text { acid methyl ester) }\end{array}$ & 100 & 100 \\
\hline 2 & 3-methylbenzoxazolinone (1b) & 0.0 & 7.1 \\
\hline 3 & 3-methyl-6-chlorobenzoxazolinone (1c) & 30.8 & 0.0 \\
\hline 4 & 3-methyl-6-bromobenzoxazolinone (1c) & 24.6 & 0.0 \\
\hline 5 & 3-propyl-6-bromobenzoxazolinone (1y) & 43.66 & 0.0 \\
\hline 6 & 3-vinylbenzoxazolione (1h) & 6.9 & 0.0 \\
\hline 7 & 3-vinyl-6-chlorobenzoxazolione (1 o) & 4.5 & 0.0 \\
\hline 8 & 3-vinyl-6-bromobenzoxazolinone $(1 \mathrm{x})$ & 0.0 & 11.1 \\
\hline 9 & 3-tritylbenzoxazolinone (1g) & 23.94 & 49.38 \\
\hline \begin{tabular}{l|l}
1 \\
0
\end{tabular} & 3- trityl-6 - chlorobenzo-sazolinone ( $1 \mathrm{p})$ & 22.53 & 39.05 \\
\hline $\begin{array}{l}1 \\
1\end{array}$ & 3-trityl-6-bromobenzoxazolinone (1ph) & 27.11 & 47.99 \\
\hline $\begin{array}{l}1 \\
2 \\
\end{array}$ & 2-methylthiobenzoxazole (2a) & 0.0 & 96.4 \\
\hline $\begin{array}{ll}1 \\
3\end{array}$ & 2-vinylthiobenzoxazole (2b) & 31.9 & 34.24 \\
\hline $\begin{array}{l}1 \\
4 \\
\end{array}$ & 2-benzylthiobenzoxazole (2c) & 29.66 & 58.61 \\
\hline $\begin{array}{l}1 \\
5\end{array}$ & $\begin{array}{l}\text { Benzoxazolyl-2-carbamic acid methyl ester } \\
\text { (3a) }\end{array}$ & 16.19 & 45.0 \\
\hline $\begin{array}{l}1 \\
6 \\
\end{array}$ & Benzoxazolyl-2-carbamic acid ethyl ester (3b) & 39.85 & 50.16 \\
\hline $\begin{array}{l}1 \\
7 \\
\end{array}$ & Benzoxazolyl-2-carbamic acid propyl ester (3c) & 25.66 & 62.58 \\
\hline $\begin{array}{l}1 \\
8 \\
\end{array}$ & Benzoxazolyl-2-carbamic acid butyl ester (3g) & 29.66 & 65.0 \\
\hline
\end{tabular}

The synthesized 3 -tritylbenzoxazolinones and alkyl esters of benzoxazolyl-2-carbamic acid have been studied as a fungicide against powdery mildew of cucumbers and wheat. Plants in the multileaf phase were treated with aqueous suspensions of the test preparations, control water. After drying, the plants were artificially infected with an aqueous suspension containing 200 thousand conidia in $1 \mathrm{ml}$ of water. The reference in the experiment was the preparation caratan (2,4-dinitro-6-fluoro-octylphenol crotanate). Cucumber variety "Multifruited VSHV", wheat "Krasnozernaya". The development of the disease for cucumbers was recorded for 10-15 days. The experiments were repeated three times [1]. 
Table 5. The activity of the synthesized compounds against the causative agent of powdery mildew.

\begin{tabular}{|c|c|c|c|c|}
\hline \multirow[b]{2}{*}{ \# } & \multirow{2}{*}{ Compound } & \multirow{2}{*}{ 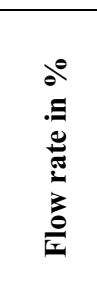 } & \multicolumn{2}{|c|}{$\begin{array}{c}\text { Suppression of the } \\
\text { development of the disease, } \\
\%\end{array}$} \\
\hline & & & $\begin{array}{l}\text { Powdery } \\
\text { mildew of } \\
\text { cucumbers } \\
\text { for } 10 \text { days }\end{array}$ & $\begin{array}{c}\text { Powdery } \\
\text { mildew of } \\
\text { wheat for } 10 \\
\text { days }\end{array}$ \\
\hline 1 & Control karatan & 0.1 & 98.0 & 100 \\
\hline 2 & 3-tritylbenzoxazolinone (1g) & 0.1 & 86.0 & 90.0 \\
\hline & \multirow{3}{*}{ 3- trityl-6 - chlorobenzo-sazolinone (1p) } & 0.1 & 80.0 & 88.0 \\
\hline 3 & & 0.5 & 69.0 & 86.0 \\
\hline & & 0.025 & 69.0 & 75.0 \\
\hline \multirow{3}{*}{4} & \multirow{3}{*}{ 3-trityl-6-bromobenzoxazolinone (1ph) } & 0.1 & 84.0 & 91.0 \\
\hline & & 0.5 & 80.0 & 86.0 \\
\hline & & 0.025 & 80.0 & 83.0 \\
\hline \multirow{3}{*}{5} & \multirow{3}{*}{$\begin{array}{l}\text { Benzoxazolyl-2-carbamic acid methyl ester } \\
\text { (3a) }\end{array}$} & 0.1 & 73 & 80 \\
\hline & & 0.5 & 70 & 77 \\
\hline & & 0.025 & 69 & 70 \\
\hline \multirow{3}{*}{6} & \multirow{3}{*}{$\begin{array}{l}\text { Benzoxazolyl-2-carbamic acid ethyl ester } \\
\text { (3b) }\end{array}$} & 0.1 & 85 & 87 \\
\hline & & 0.5 & 77 & 82 \\
\hline & & 0.025 & 64 & 69 \\
\hline \multirow{3}{*}{7} & \multirow{3}{*}{$\begin{array}{l}\text { Benzoxazolyl-2-carbamic acid propyl ester } \\
\text { (3c) }\end{array}$} & 0.1 & 80 & 84 \\
\hline & & 0.5 & 76 & 80 \\
\hline & & 0.025 & 68 & 71 \\
\hline \multirow{3}{*}{8} & \multirow{3}{*}{$\begin{array}{l}\text { Benzoxazolyl-2-carbamic acid butyl ester } \\
(3 \mathrm{~g})\end{array}$} & 0.1 & 85 & 91 \\
\hline & & 0.5 & 80 & 88 \\
\hline & & 0.025 & 69 & 76 \\
\hline
\end{tabular}

As a result of the work carried out, it was found that the tested substances do not have a phytotoxic effect, do not inhibit the growth and development of plants. As the data in Table 5 show, 3-tritylbenzoxazolinones exhibit fungicidal action against the causative agent of cucumber powdery mildew - Erysiphe cichoracearum and wheat powdery mildew Erysiphe graminis approaching control. Alkyl esters of benzoxazolyl-2-carbamic acid also showed a fungicidal effect against the pathogen of cucumber powdery mildew - Erysiphe cichoracearum and wheat powdery mildew - Erysiphe graminis inferior to the control.

At the same time, the tested chemicals suppressed the development of the disease on days 10 and 15, and did not show activity on day 20. Among the discussed compounds, benzoxazolyl-2-carbamic acid butyl ester had the greatest activity against cucumber powdery mildew. The same pattern is observed against the causative agent of wheat powdery mildew. Perhaps this is due to the greater lipophilicity of the molecule.

Thus, the influence of individual structural characteristics on the fungicidal activity of more than 26 compounds was determined. The greatest fungicidal activity was shown by $2-$ methylthiobenzoxazole which suppressed the development of spores of the fungi Verticillum dahlia. The biological effectiveness of its action in the growing experiment was 96.4\%. It was noted that 3-tritylbenzoxazolinones and alkyl esters of benzoxazolyl-2carbamic acid exhibit a fungicidal effect against the causative agent of cucumber powdery mildew - Erysiphe cichoracearum and wheat powdery mildew - Erysiphe graminis, which is 
close to the control, among them, butyl 2-benzoxazalamide acid powdery mildew of cucumbers $(91 \%)$.

\section{Conclusions}

Thus, the influence of individual structural characteristics on the herbicidal activity of 28 compounds and on the fungicidal activity of more than 26 compounds was determined. 3 alkylbenzoxazolinones, 3-alkyl-6-halobenzoxazalinones, and 2-alkylthiobenzoxazoles showed herbicidal action during the growing season of plants. Among them, 2methylthiobenzoxazole exhibits a high percentage of weed suppression. Extensive field trials carried out in recent years have confirmed the high herbicidal activity of this compound. Using the $\mathrm{C}$ Hansch correlation equation, it was established that the manifestation of herbicidal activity is of decisive importance for the electronic characteristics of the substituents. The greatest fungicidal activity was exhibited by 2methylthiobenzoxazole, which suppressed the development of spores of the fungi Verticillum dahlia. The biological effectiveness of its action in the growing experiment was 96.4\%. It was noted that 3-tritylbenzoxazolinones and alkyl esters of benzaxazolyl-2carbamic acid exhibit a fungicidal effect against the causative agent of cucumber powdery mildew - Erysiphe cichoracearum and wheat powdery mildew - Erysiphe graminis. Benzaxazolyl 2-carbamic acid butyl ester, which had the highest activity against cucumber powdery mildew (91\%), also has a high efficiency at the control level.

\section{References}

1. S. Isaev, I. Begmatov, G. Goziev, S. Khasanov, IOP Conf. Ser.: Mater. Sci. Eng., 883(1), 012080 (2020)

2. O. A. Monastyrskiy, A. P. Glinushkin, M. S. Sokolov, Agrochemistry, 11, 3-11 (2016)

3. N. Teshaev, B. Mamadaliyev, A. Ibragimov, S. Khasanov, InterCarto. InterGIS, 26(3), 324-333 (2020)

4. M. I. Olimova, N. S. Mukhamedov, B. ZH. Elmuradov, Chemistry and Chemical Technology, 4(55), 21-23 (2016)

5. S. K. Isaev, R. U. Rakhmonov, S. S. Tadjiev, G. I. Goziev, S. Z. Khasanov, IOP Conf. Ser.: Earth Environ. Sci., 614(1), 012147 (2020),

6. A. P. Glinushkin, A. V. Ovsyankina, M. I. Kiseleva, T. M. Kolomiets, Russian agricultural science, 2, 19-25 (2018)

7. R. A. Kulmatov, S. A. Adilov, S. Khasanov, IOP Conf. Ser.: Earth Environ. Sci., 614(1), 012149 (2020)

8. V. Strel'tsova, A. Sevryugina, Y. Spiridonov, A. Ovsyankina, A. Gerner, IOP Conf. Ser.: Earth Environ. Sci., 390(1), 123-136 (2019)

9. V. A. Semykin, I. Y. Pigorev, A. A. Tarasov, A. P. Glinushkin, S. A. Plygun, I. I. Sycheva, Russian Journal of Agricultural and Socio-Economic Sciences, 11(59), 3-9 (2016)

10. A. Jumanov, S. Khasanov, A. Tabayev, G. Goziev, U. Uzbekov, E. Malikov, IOP Conf. Ser.: Earth Environ. Sci., 614(1), 012150 (2020)

11. R. Kulmatov, A. Taylakov, S. Khasanov, Environ. Sci. Pollut. Res., 28(10), $12245-$ 12255 (2021)

12. I. Aslanov, S. Khasanov, Y. Khudaybergenov, M. Groll, Ch. Opp, F. Li, E. Ramirez Del-Valle, E3S Web Conf., 227, 02005 (2021) 
13. YA. A. Mandelbaum, G. E. Nikishova, I. N. Nagayuk, P. N. Zaks, P.G. Fozalon, Chem. means of protection rast., 1, 25-28 (1970) (in Russian)

14. S. Isaev, S. Khasanov, Y. Ashirov, T. Karabaeva, A. Gofirov, E3S Web Conf., 244, $02012(2021)$

15. R. J. Khim, 12, 631 (1994)

16. S. Isaev, S. Khasanov, Y. Ashirov, A. Gofirov, T. Karabaeva, E3S Web Conf., 244, 02047 (2021)

17. N. A. Aliev, K. Giyasov, R. G. Aflyatunova, Synthesis of biologically active substances in the series of benzoxazolinone and benzoxazolinethione Fungicides, 4665 (1980)

18. K. Giyasov, Uzbek. chem. Zh., 2, 77-84 (2019)

19. K. Giyasov, Z. Mukhidova, Uzbek. chem. Zh., 2, 69-74 (2018)

20. K. Giyasov, B. Sapaev, L. T. Zhuraeva, G. S. Turaeva, I. Yu. Podkovyrov, Izvestia NV AUK, 3(59), 198-205 (2020)

21. B. T. Kratky, G. F. Warren, Weed Sci, 19(6), 658 (1974)

22. A. T. Ayupova, L. V. Molchanov, CH. SH. Kadyrov, N. A. Aliev, K. Giyasov, N. P. Loy, Z. Tsoi, A. A. Umarov, Agrochemistry, 10, 107-111 (1970) 